\title{
Herbicides Effect on Nitrogen Cycling in Agroecosystems
}

\author{
Damin, $\mathrm{V}^{1}$. and Trivelin P.C.O. ${ }^{2}$ \\ ${ }^{1}$ Universidade Federal de Goiás, Escola de Agronomia e \\ Engenharia de Alimentos, Dep. de Ciência do Solo, Goiânia, GO \\ ${ }^{2}$ Centro de Energia Nuclear na Agricultura, Lab. Isótopos \\ Estáveis. Av. Centenário, $n^{\circ}$ 303, Caixa Postal 96, \\ CEP 13416-000, Piracicaba, SP \\ Brazil
}

\section{Introduction}

With the widespread use of post-emergent herbicides and their increased use in areas under conservation management systems (no-till and minimum tillage), concerns about environmental and public health problems due to herbicidal molecules has been growing. The use of herbicides has been justified by the resultant reduction in production costs because expenses regarding application and product price are lower with these treatments compared with existing alternatives. However, studies in the literature have demonstrated that there can be an increasing need for greater doses of nitrogen $(\mathrm{N})$ fertilizers and pesticides after herbicides have been applied (Cakmak, 2007; Damin et al., 2008, 2009).

The use of nitrogen fertilizers in doses that are enough to supply the demand of crops is one of the main practices associated with high productivity. However, these fertilizers are expensive, and their indiscriminate use can cause the emission of green-house gases (Sherlock et al., 1989), the contamination of superficial waters with nitrate and the destruction of ozone in the stratosphere, with $\mathrm{N}_{2} \mathrm{O}$ as an intermediary (Groffman, 2000). In addition, fossil fuels, which are non-renewable resource, are consumed in the manufacture of $\mathrm{N}$ fertilizers.

Recent research has shown that about 15 to $20 \%$ of the $\mathrm{N}$ introduced by fertilization can be lost after plants have been desiccated by herbicides. This losses can be even greater when the $\mathrm{N}$ that was already in the system is considered. Moreover, some laboratory studies have shown an increase in the emission of $\mathrm{N}_{2} \mathrm{O}$, a gas that has a global heating potential 298 times greater than that of $\mathrm{CO}_{2}$, in areas using desiccants.

Despite the importance of awareness about the effects of herbicides in the nitrogen cycle, this subject has been seldom discussed and studied in the literature. Within this context, this chapter will discuss the effects of herbicides in the nitrogen cycle processes that determine its availability to plants in agricultural systems.

\section{Nitrogen in the agroecosystems}

In an attempt to minimize the production costs and environmental impacts that occur because of the use of $\mathrm{N}$ fertilizers, the adoption of management strategies that minimize the 
$\mathrm{N}$ losses in agroecosystems has been proposed. Such strategies include the efficient application of $\mathrm{N}$ at the moment the crop needs it most. $\mathrm{N}$ presents a great difficulty, however, because it is a highly reactive element that is subject to various changes in the soil and in plants (Moreira \& Siqueira, 2006). Most of the changes of $\mathrm{N}$ in soil are intermediated by the microbial community, which fluctuates in both time and space. Therefore, besides properties such as $\mathrm{pH}$, organic matter and CTC content, $\mathrm{N}$ dynamic is influenced by factors that affect the microbiota. These factors include aeration, water availability and the presence of toxic or stimulants substances to microorganisms.

The effects of herbicides on soil microbiota depend on the mechanism and other features of the product; type of metabolism of the microorganism (e.g., photolithotrophic, photoorganotrophic, chemolithotrophic, chemoorganotrophic), which determines if the metabolic routes that are affected by the herbicide are present in the microorganism; and also edaphic and climatic factors. Some herbicides, such as the paraquat, are toxic to biota in general. Others, such as glyphosate and glufosinate ammonium show low toxicity to nontarget organisms. In fact, an increase in microbial biomass after the application of these products has been observed in some situations. This result has been attributed to the products serving as a source of nutrients. It is worth stressing, however, that some studies have shown that glyphosate is toxic to some organisms, such as certain strains of nitrogenfixing bacteria (NFB).

Besides affecting processes of the $\mathrm{N}$ cycle that are intermediated by the microbiota, the herbicides can change the metabolism of $\mathrm{N}$ inside the plant, depending on the mechanism of the product. The herbicide glufosinate ammonium, for example, inhibits the incorporation of $\mathrm{NH}_{4}{ }^{+}$in organic compounds. This effect can cause a build-up of $\mathrm{NH}_{4}{ }^{+}$in vegetal tissue. Because its ions are toxic to plants, part of the accumulated $\mathrm{NH}_{4}{ }^{+}$can be exuded through the roots and/or converted into $\mathrm{NH}_{3}$ and lost in the atmosphere, reducing the $\mathrm{N}$ availability in the system. The exit of $\mathrm{N}$ from the plant can increase the $\mathrm{C} / \mathrm{N}$ relation of the formed stubble, thus reducing its mineralization rate.

Some of the processes of the $\mathrm{N}$ cycle and the effect desiccant herbicides have over them are presented below.

\subsection{Nitrogen losses}

Among the main forms of nitrogen loss in agroecosystems are removal by crop, the volatilization of soil ammonium, the gas loss of nitrogen oxides $\left(\mathrm{NO}_{2}, \mathrm{~N}_{2} \mathrm{O}, \mathrm{NO}\right)$ and elemental nitrogen $\left(\mathrm{N}_{2}\right)$, the lixiviation of soil nitrate leaving the root system's target range and $\mathrm{NH}_{3}$ loss by the aerial parts of plants.

Sutton et al. (1993) reported that losses of nitrogen by the aerial parts of vegetables can increase ammonium levels in the atmosphere, noting emission values ranging from $5-15 \mathrm{~kg}$

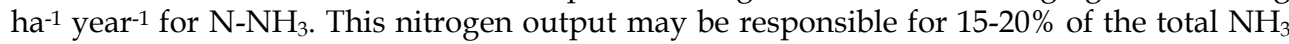
gas emissions (Asman et al., 1998).

The magnitude of nitrogen losses through the aerial parts of crops varies according to each species. Wetselaar \& Farquhar (1980) estimated from research available in the literature that the total $\mathrm{N}$ losses through the aerial parts of wheat, rice, grassy sorghum, cotton and rye crops were within a range of 16 to $40,48,48,21$ and $42 \mathrm{~kg}^{-1} \mathrm{~N}$, respectively. For barley crops, Schjoerring et al. (1993) found losses of $1-2 \mathrm{~kg}^{-1}$ year-1 of $\mathrm{N}^{-1} \mathrm{NH}_{3}$ under three fertilization regimes with N. For corn, Francis et al. (1993) found losses of 45 to $81 \mathrm{~kg} \mathrm{ha}^{-1} \mathrm{~N}$, with application rates ranging from 50 to $300 \mathrm{~kg} \mathrm{ha}^{-1} \mathrm{~N}$. $\mathrm{NH}_{3}$ losses through the aerial parts of sugar cane were indirectly estimated by Trivelin (2000) at around $50 \mathrm{~kg} \mathrm{ha}^{-1} \mathrm{year}^{-1}$. This number represents half of the dose of $\mathrm{N}$ fertilizer applied to the crop sprouts. 
Aside from its effects on various species, $\mathrm{N}$ losses can be linked to the developmental stages of plants, $\mathrm{N}$ availability in the soil, stomatal conductance, leaf temperature, $\mathrm{NH}_{3}$ concentrations in the atmosphere, ammonium concentrations in the plant, the activity of the glutamine sinthetase enzyme and environmental stresses (Schjoerring et al., 1998; Parton et al., 1988). Another important factor that affects not only the intensity but also the way in which ammonium gas is exchanged among leaves and the atmosphere is the ammonium compensation point, which was defined by Farquhar et al. (1980). When $\mathrm{NH}_{3}$ concentrations in the atmosphere are below the ammonium compensation point of the plant, emission will occur through the leaves; for concentrations above, it is absorbed (Farquhar et al., 1980; Holtan-Hartwig \& Bockman, 1994).

Senescence is the developmental stage that shows the highest $\mathrm{NH}_{3}$ emission potential. During this stage, there is an increase in protein degradation, and the liberated $\mathrm{N}$ is transferred to the glutamate. Afterward, the glutamate $\mathrm{N}$ is converted to $\mathrm{NH}_{4}{ }^{+}$by the glutamate dehydrogenase (GDH) enzyme. GDH is an enzyme of $\mathrm{N}$ metabolism that usually reaches a higher degree of activity during senescence (Ragster \& Chrispeels, 1981; Laurière \& Daussand, 1983). $\mathrm{NH}_{4}{ }^{+}$is available for transformation in the composts of $\mathrm{N}$ transport, such as glutamine and asparagine (Ghosh et al., 1995; Nakasathien et al., 2000), and some of the ions are converted into $\mathrm{NH}_{3}$ according to the following balanced reaction:

$$
\mathrm{NH}_{4}{ }^{+} \leftrightarrow \mathrm{NH}_{3}+\mathrm{H}^{+} \quad \mathrm{pKa}=9.2
$$

When the $\mathrm{pH}$ is $9.2,50 \%$ of the molecules are dissociated $\left(\mathrm{NH}_{4}^{+}\right)$, and $50 \%$ are in the molecular form $\left(\mathrm{NH}_{3}\right)$. In the cytoplasm, the $\mathrm{pH}$ is usually around 7.2. At this $\mathrm{pH}$ value, only $1 \%$ of the molecules are in the $\mathrm{NH}_{3}$ form. However, it is important to stress that the $\mathrm{NH}_{4}{ }^{+}$build-up in the cytoplasm can promote $\mathrm{H}^{+}$exit to the apoplast, transiently increasing the interior $\mathrm{pH}$ of the cell and, consequently, the $\mathrm{NH}_{3}$ concentration (Britto \& Kronzucker, 2002). There is evidence that $\mathrm{NH}_{3}$ transport is easier through membranes (Kleiner, 1981), and that it can be stomatally lost.

\subsubsection{Effect of herbicides}

Herbicides are used in agricultural areas to induce the senescence of plants. The duration of the senescence phase deriving from herbicide application is very short, and the intervention may occur at any developmental stage. Therefore, it is possible that the behavioral standards of $\mathrm{N}$ are different from those observed in natural senescence conditions. Besides inducing senescence, glyphosate and glufosinate ammonium herbicides also affect the plant's $\mathrm{N}$ metabolism.

The herbicidal action of glyphosate is attributed to its inhibition of the EPSPs (enolpyruvylshikimate phosphate synthase) enzyme that is responsible for one of the synthesis phases of the tryptophan amino acids phenylalanine and tyrosine. However, as a secondary effect, there is an inhibition in the synthesis of phenolic compounds deriving from those amino acids, which increases the activity of the PAL (phenylalamine ammonia lyase) enzyme due to a response effect (Duke \& Hoagland, 1985). The PAL acts in the lyase of phenylalanine and tyrosine amino acids, resulting in the formation of phenolic acids and $\mathrm{NH}_{4}{ }^{+}$(Hoagland et al., 1979).

The glufosinate ammonium herbicide inhibits the action of the glutamine sinthetase, which is responsible for the glutamate synthesis from ammonium and glutamine. This metabolic route is considered the main form of ammonium assimilation in organic composts (Schjoerring et al., 1998). Consequently, the application of glufosinate ammonium results in endogenic $\mathrm{NH}_{4}{ }^{+}$in the plant (Manderscheid et al., 2005). 
Therefore, the increase of $\mathrm{NH}_{4}{ }^{+}$in plants desiccated with glyphosate and glufosinate ammonium should not be connected to the induction senescence alone. Damin et al. (2010b) quantified $\mathrm{N}$ losses by Brachiaria decumbens after desiccation with glyphosate, glufosinate ammonium and paraquat, all of which promoted senescence. However, only the first two increased the losses of $\mathrm{N}$ in the system.

Manderscheid et al. (2005) assessed the ammonium concentration in five weed species after applying glufosinate ammonium. They observed an $\mathrm{NH}_{4}{ }^{+}$increase in studied species. Damin et al. $(2008$; 2010a) observed losses of around 10 to $20 \%$ of applied N fertilizer after the application of glyphosate and glufosinate ammonium in Brachiaria decumbens and Pennicetum glaucum (Table 1). In those same studies, a reduction of around $40 \%$ of the total$\mathrm{N}$ in the plant was observed after the application of herbicides.

From a practical point of view, the effect of herbicides on the total $\mathrm{N}$ of plants used for soil covering is important because it can affect the mineralization rate due to a raise in the C:N ratio, and it can effect the immobilization of $\mathrm{N}$ by soil microorganisms, a process that reduces the nutrient's availability to plants.

\section{3. $\mathbf{N}$ mineralization/immobilization}

When organic residue is added to the soil, extra-cellular enzymes are liberated by the biota, which degrade the residue into substances with smaller molecular weights (monomers). These monomers are absorbed and metabolized by microbial cells, which transform them into inorganic forms, a process called mineralization. Mineralization occurs at the same time as immobilization, which refers to the incorporation of mineral nutrients to the microbial cells to meet the nutritional demand of the soil microbiota.

\begin{tabular}{|c|c|c|c|c|c|c|c|c|c|c|}
\hline \multirow[t]{2}{*}{ Treatments } & \multicolumn{2}{|c|}{$\begin{array}{l}\text { Above ground } \\
\text { part }\end{array}$} & \multicolumn{2}{|c|}{ Roots } & \multicolumn{2}{|c|}{ Entire plant } & \multicolumn{2}{|c|}{ Soil } & \multicolumn{2}{|c|}{$\begin{array}{l}\text { Losses on } \\
\text { soil-plant } \\
\text { system }\end{array}$} \\
\hline & P. g. 1 & B. d. ${ }^{2}$ & P. g. 1 & B. d. ${ }^{2}$ & P. g. ${ }^{1}$ & B. d. ${ }^{2}$ & P. g. 1 & B. d. ${ }^{2}$ & P. g. ${ }^{1}$ & B. d. ${ }^{2}$ \\
\hline & $\mathrm{g} \mathrm{m}^{-2}$ & & & & & & & & & \\
\hline Control & $13.8 \mathbf{a}$ & 11.5 & $3.4 \mathbf{a}$ & $6.1 \mathbf{a}$ & $17.2 \mathbf{a}$ & $17.6 \mathbf{a}$ & $2.4 \mathrm{~b}$ & $2.1 \mathrm{~b}$ & $5.4 \mathrm{~b}$ & $9.9 \mathrm{~b}$ \\
\hline Glyphosate & $10.8 \mathbf{b}$ & 8.1 & $2.7 \mathrm{~b}$ & $2.9 \mathrm{~b}$ & $13.6 \mathbf{b}$ & $11.1 \mathbf{b}$ & $3.4 \mathbf{a}$ & $3.4 \mathbf{a}$ & $8.0 \mathrm{a}$ & $15.1 \mathbf{a}$ \\
\hline Glufosinate & $11.0 \mathrm{~b}$ & 8.1 & $2.0 \mathrm{~b}$ & $2.4 \mathrm{~b}$ & $12.9 \mathbf{b}$ & $10.5 \mathbf{b}$ & $4.0 \mathrm{a}$ & $3.1 \mathbf{a}$ & $8.0 \mathrm{a}$ & $16.0 \mathbf{a}$ \\
\hline $\operatorname{LDS}(0,05)$ & 2.1 & 3.8 & 0.5 & 1.8 & 3.0 & 4.9 & 0.7 & 0.8 & 2.3 & 4.9 \\
\hline$P$ & $* *$ & ns & * & $* *$ & $* *$ & $* *$ & * & $* *$ & * & * \\
\hline C.V. (\%) & 19.2 & 26.3 & 31.7 & 32.3 & 8.9 & 25.1 & 28.3 & 18.9 & 14.9 & 24.2 \\
\hline
\end{tabular}

${ }^{1}$ Measurement of ten replicates. ${ }^{2}$ Measurement of six replicates. ${ }^{*}$ Means followed by different letters in columns differ from each other by Tukey's Test $(\boldsymbol{\alpha}=0.05) .{ }^{* *}$ Means followed by different letters in columns differ from each other by Tukey's Test $(\mathbf{\alpha}=0.01)$. The total dose of $\mathrm{N}$ was $25 \mathrm{~g} \mathrm{~m}^{-2}$ in pearl millet and $15 \mathrm{~g} \mathrm{~m}^{-2}$ in signal grass.

Table 1. Data of N recovered and lost from ${ }^{15} \mathrm{~N}$-labeled fertilizer (Ndff) in the soil-plant system after herbicide application in Brachiaria decumbens (B.d.) and Pennicetum glaucum (P.g.). Retrieved from Damin et al. (2010a). 
From the incorporation of vegetable residues in soil to their mineralization, several living organisms act in this process. In the initial phase, the vegetable residues are fragmented into smaller litter by the soil's macro-fauna. Subsequently, a diverse microbial community acts to liberate extra-cellular enzymes, which turn the substances that are easily decomposed into monomers that can then be absorbed by microbial cells. Substances that are difficult to degrade, such as cellulose and lignin, are degraded by a more specialized group of microorganisms, which compose the secondary and tertiary mineralizers.

Residues that are rich in lignin and polyphenols have slower mineralization rates in the soil due to the resistance these substances have to degradation (Moreira \& Siqueira, 2006; Oliveira et al., 2002). The $\mathrm{C} / \mathrm{N}$ ratio also has a major influence on the mineralization rate of vegetable residues, as it determines the $\mathrm{N}$ availability in the microbiota. Crop residues with a C/N ratio around 15:1 to 20:1 (e.g., soybeans, beans, lupine, forage turnips) tend to degrade faster than those with a $\mathrm{C} / \mathrm{N}$ ratio higher than 30:1 (e.g., black oat, pearl millet, corn, sorghum). Heinzmann (1985) studied the $\mathrm{N}$ dynamics after winter green fertilization with black oat, forage turnip, hairy vetch, lupine and wheat and their effects on soy, corn and bean crops. He observed that the $\mathrm{N}$ liberation from legume and forage turnip residues occurred in the first weeks, whereas the black oat liberated more $\mathrm{N}$ in the blooming and graining stages.

\subsection{Effect of herbicides}

In addition to chemical composition, the mineralization of crop residues added to the soil depends on factors that affect the composition and activity of the decomposing microbial community. These factors include temperature, humidity, aeration and the presence of toxic or nurturing substances. Concerning the effect of herbicides on mineralization rates, some observations should be made: 1) Herbicides can increase vegetable residue decomposition rates due to a greater detachment of leaves and roots caused by senescence. Thus, they may have a beneficial physical effect on stubble mineralization (Snapp \& Borner, 2005). 2) However, the increased $\mathrm{C} / \mathrm{N}$ ratio in the stubble caused by the application of these products may decrease the mineralization rate. 3) Furthermore, these herbicidal molecules may alter the soil's microbial community and cause an increase or a decrease in mineralization, depending on the affected microorganism populations.

Argenta et al. (2001) observed an increase in the C:N ratio on the aerial parts of black oats 16 days after the application of glyphosate, glufosinate and paraquat. Although the paraquat did not decrease the $\mathrm{N}$ content of the plant during senescence, there was a remobilization of the nutrient to the reproductive structures and to the root system (Marschner, 1995). With the increase in the $\mathrm{C} / \mathrm{N}$ ratio, the stubble mineralization rate can decrease. In fact, Damin et al. (2009; 2010c) assessed the $\mathrm{N}$ decomposition rate present in pearl millet and black oat stubble after the application of glyphosate and glufosinate ammonium. They observed an increase in the stubble dry matter remaining on the soil surface and a decrease in $\mathrm{N}$ liquid mineralization (Tables 2 and 3). In their studies, the absorption of $\mathrm{N}$ in stubble (enriched with ${ }^{15} \mathrm{~N}$ ) by corn plants was also assessed, and the herbicide-treated stubble was observed to be less effective in supplying $\mathrm{N}$ to plants.

The mineralization of organic substances is mainly mediated by chemoorganotrophic microorganisms, which should not be damaged by the application of glyphosate and glufosinate ammonium because these herbicides act on metabolic routes that are typical of lithotrophic organisms (chemolithotrophic or photolithotrophic). Therefore, the reduction in mineralization observed by Damin et al. (2009; 2010c) was attributed to the increase in the stubble C/N ratio. 
In fact, Acinelli et al. (2002) observed that the application of the recommended doses of glyphosate and glufosinate ammonium did not interfere in the activity or in the soil microbial carbon biomass. The application of higher doses than recommended resulted in greater microbial activity, which can be connected to the death of lithotrophic micro-organisms, ensuring a competitive advantage to heterotrophs. Similar results were found for glyphosate by Haney et al. (2000), Ratcliffe et al. (2006) and Zabaloy \& Gómez (2008).

Some studies have shown that the $\mathrm{N}$ mineralization that is already in the soil is increased by the application of glyphosate. Grossbard (1985) assessed the effect of glyphosate on soil N mineralization and observed an increase in mineralization when the herbicide was used. Haney et al. (2002) evaluated under laboratory conditions the effect of applying atrazine a mix of atrazine and glyphosate on the mineralization of total- $\mathrm{C}$ and total-N present in the soil. These authors observed a greater $\mathrm{C}$ and $\mathrm{N}$ mineralization in the soil treated with the mixture. The results showed that the glyphosate favored the chemoorganotrophic microbiota, causing an increase in the soil edaphic organic matter mineralization.

In tillage systems in Brazil's Cerrado, a reduction in deposited stubble mineralization is desirable because it increases the permanence time of residue over the soil. However, the lower effectiveness of the residue in supplying $\mathrm{N}$ to plants and microorganisms can reduce productivity when the $\mathrm{N}$ supply through fertilization is not appropriate because the addition of low $\mathrm{N}$ content organic residues to the soil results in the immobilization of the nutrient by the microbiota, reducing its availability to plants. Therefore, the use of herbicides for covering crop desiccation in tillage system should be considered in the decision making processes of $\mathrm{N}$ fertilization management.

\begin{tabular}{|c|c|c|c|c|c|c|c|}
\hline Treatments & DM & Carbon & Nitrogen & $\mathrm{C}: \mathrm{N}$ & $\Delta \mathrm{DM}$ & $\Delta \mathrm{C}$ & $\Delta \mathrm{N}$ \\
\hline & $-g$ & er pot- & $\mathrm{mg}$ per pot & & 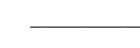 & $\%$ & \\
\hline Control & $6.5 \mathrm{~b}$ & $2.6 \mathrm{~b}$ & $117.2 \mathrm{~b}$ & $22.6 \mathrm{~b}$ & $49.9 \mathrm{a}$ & $49.4 \mathrm{a}$ & $69.6 \mathrm{a}$ \\
\hline Glyphosate & $8.5 \mathrm{a}$ & $3.7 \mathrm{a}$ & 159.9 a & $24.3 \mathrm{~b}$ & $34.1 \mathrm{~b}$ & $22.1 \mathrm{~b}$ & $51.8 \mathrm{~b}$ \\
\hline Glufosinate & $9.3 \mathrm{a}$ & $3.8 \mathrm{a}$ & $160.2 \mathrm{a}$ & $28.6 \mathrm{a}$ & $28.3 \mathrm{~b}$ & $23.2 \mathrm{~b}$ & $49.7 \mathrm{~b}$ \\
\hline F-test & $* *$ & $* *$ & $* *$ & * & $* *$ & $* *$ & $* *$ \\
\hline $\mathrm{CV}(\%)$ & 15.5 & 13.6 & 16.2 & 12.4 & 25.6 & 30.3 & 12.3 \\
\hline
\end{tabular}

Table 2. Dry mass, carbon, nitrogen, and C:N ratio in above-ground parts of black oat treated with herbicides at 101-days-old grown in soil.

\section{4. $\mathbf{N}$ exuding through the roots}

The rhizosphere may be defined as the soil zone that is influenced by the roots. The deposition of exuded matter and root fragments in this region favors the growth and activity of the soil microbial community, which has important functions in cycling and in the supply of nutrients to plants, especially N. About $15 \%$ of the total $\mathrm{CO}_{2}$ set by plants is deposited in the rhizosphere in a cereal crop cycle (Nguyen, 2003). Sugars, amino acids, 
organic acids, phenols, exoenzymes and ions such as $\mathrm{NH}_{4}{ }^{+}$are the main compounds exuded by the roots (Kraffczyk et al., 1984; Marschner, 1995; Dakora \& Phillips, 2002; Nguyen, 2003; Paterson, 2003).

Exudation may be an important way for $\mathrm{N}$ to exit the plant. Klein et al. (1988) estimated that the C:N ratio of exuded compounds for the Poaceae family species ranged from 2 to 2.7. However, other studies have demonstrated that the exuding of compounds containing $\mathrm{N}$ is very low, and the exuded compounds are rich in sugars (Deubel et al., 2000; Paterson, 2003; Merbach et al., 2003). The main factors affecting the amount and composition of material exuded from the roots are vegetable species, plant development stage, environmental stress, nutritional state, injuries, application of chemical products and activity and composition of the soil microbial community (Marschner, 1995; Holland et al., 1996).

\begin{tabular}{|c|c|c|c|}
\hline Treatments & $\begin{array}{c}\text { Net } \mathrm{N} \\
\text { mineralization }\end{array}$ & Non-recovered & Soil - Plant \\
\hline Control & $201.2 \mathrm{a}$ & 52.9 & $418.0 \mathrm{a}$ \\
\hline Glyphosate & $150.0 \mathrm{~b}$ & 43.9 & $383.9 \mathrm{ab}$ \\
\hline Glufosinate & $148.5 \mathrm{~b}$ & 74.6 & $368.3 \mathrm{~b}$ \\
\hline F-test & $* *$ & NS & * \\
\hline CV (\%) & 8.8 & 54.6 & 8.9 \\
\hline Control & $42.3 \mathrm{a}$ & 11.2 & 88.8 \\
\hline Glyphosate & $35.3 \mathrm{~b}$ & 10.3 & 90.2 \\
\hline Glufosinate & $33.5 \mathrm{~b}$ & 16.8 & 83.1 \\
\hline F-test & $* *$ & NS & NS \\
\hline CV (\%) & 8.7 & 55.4 & 8.8 \\
\hline
\end{tabular}

Means followed by the same letter in a given column indicates nonsignificant differences at the $5 \%$ level by Tukey's test; ** ${ }^{*}=$ Significant at $1 \%$ and $5 \%$ levels, respectively; $N \mathrm{~S}=$ nonsignificant difference.

Table 3. Net N mineralization, non-recovered fraction and soil-plant recovery of the nitrogen arising from black oat residue with or without herbicide previous application.

\subsection{The effect of herbicides in exudated $\mathrm{N}$}

Herbicides may affect some of the mentioned factors and, consequently, root exudation. Kremer et al. (2005) evaluated amino acid and carbohydrate exudation after glyphosate was applied to conventional crops and crops genetically modified for herbicide tolerance. They concluded that the exudation was stronger in both crops after the product was applied. Similar results were obtained in bean plants that were desiccated with glyphosate (Liu et al., 1997). These authors found aspartic acid, glutamic acid, serine, glycine, amino butyric acid, valine, isoleucine, leucine, tyrosine, phenylalanine and proline in the material exuded from the roots. They observed that the valine, isoleucine and glycine concentrations were higher in the plants desiccated with the product.

The herbicides that were used as a replacement for the glyphosate also increased root exudation. Damin et al. (2010b) evaluated the compound exudation containing $\mathrm{N}$ and the root detachment in Brachiaria decumbens plants after the application of glyphosate, glufosinate ammonium and paraquat. They observed an increase in exudation (Figure 1) and the detachment of roots after the application of three products. Paraquat, unlike 
glyphosate and glufosinate ammonium, does not have its action connected to the $\mathrm{N}$ metabolism of the plant. As all herbicides increase $\mathrm{N}$ exudation, this process is probably not connected exclusively to the product's active mechanism. Physiologic events characteristic of senescence could justify the results obtained in this research. However, Kremer et al. (2005) observed that the exudation of sugars and amino acids was higher in soybeans genetically modified for tolerance to glyphosate than in the conventional soybeans. In this case, the increase in exudation was not connected to the development of senescence after the application of the herbicide.

It is worth stressing that the losses from exudation and root detachment together represented less than $4 \%$ of the $\mathrm{N}$ applied to the entire plant and, therefore, they should not affect in a relevant way the $\mathrm{N}$ content of the same plant (Damin et al., 2010b). The compound $\mathrm{N}$ exudation, notwithstanding, may modify the composition and activity of the soil microbial community due to the supply of carbon sources that are highly soluble and readily available.

There is a great diversity of microorganisms in the soil, which, according to the kind of nutrition, may be grouped in photolithotrophic, photoorganotrophic, chemolithotrophic and chemoorganotrophic. Phototrophic microorganisms (photolithotrophic and photoorganotrophic) are rare, and chemotrophic microorganisms are abundant in the soil. All kinds of fungi are chemoorganotrophic, i.e., they use organic molecules as a source of carbon and energy, whereas bacteria and actinomycetes may come from a variety of groups. Processes such as nitrification and $\mathrm{N}$ biological fixation are mainly mediated by chemolithotrophic organisms, which use $\mathrm{CO}_{2}$ as a carbon source and obtain energy from inorganic compound oxidation (Moreira \& Siqueira, 2006).

Due to the nutritional type, the supply of easily decomposable organic carbon sources caused by exudation offers a competitive advantage to chemoorganotrophic microorganisms, modifying the proportion of microorganism populations in the soil microbial community. In addition, chemoorganotrophs may be favored by the use of herbicides such as glyphosate and glufosinate, which act in metabolic routes that are present only in lithotrophic organisms (photolithotrophic and chemolithotrophic).

Among the chemoorganotrophic microorganisms that are important for agriculture are the decomposers of organic residues and most of the plants' pathogens. Kremer et al. (2005) observed an increase in fungi biomass of the kind Fusarium sp. after the application of glyphosate to soybeans. Liu et al. (1997) observed an increase in the number of colonies and a higher development of the Pytium sp. fungi after addition to the environment through the bean roots cultivated with glyphosate desiccated or exuded herbicide. As the glyphosate can also be exuded by the roots (Kremer et al., 2005; Tuffi Santos et al., 2008), it is possible that the population increase of pathogenic microorganisms after the application of the herbicide is connected to the $\mathrm{N}$ compound exudation as well as to the presence of the herbicide.

Aside from those processes, a higher colonization of roots by pathogenic microorganisms may be associated with the effects the herbicide has on the plant's defense system. Liu et al. (1997) also observed that bean plantlets growing in the middle of Pytium sp. showed a higher lignin content when glyphosate was not added to the environment. Studies in sterile environments have shown that the increase in Pythium and Fusarium sp. is connected to the effectiveness of the glyphosate herbicide (Johal \& Rahe, 1984; Levesque \& Rahe, 1992; Levesque et al., 1992; Levesque et al., 1993; Descalzo et al., 1996). 


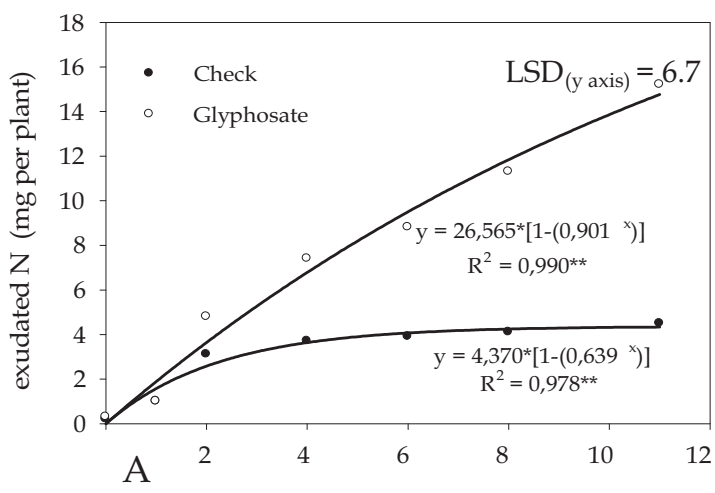

DAA
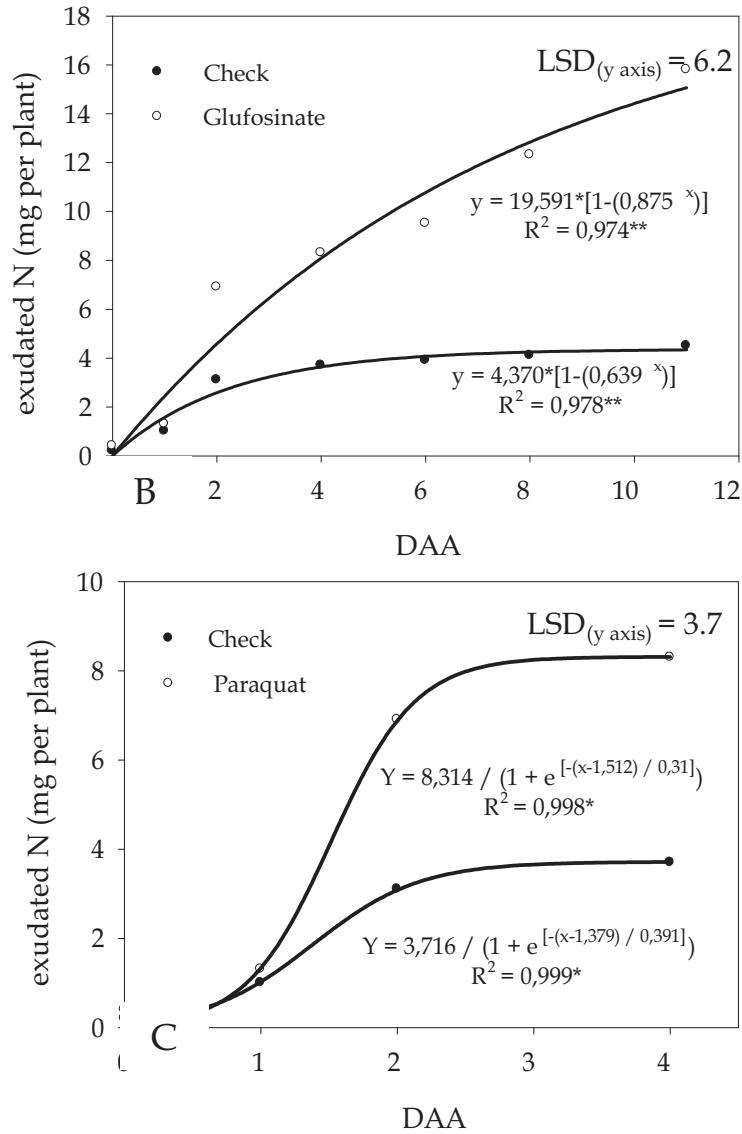

Fig. 1. Time accumulated exudation of nitrogen after herbicide application on Brachiaria decumbens Stapf. A - Glyphosate $\left(\mathrm{F}_{\text {herb }}=2.8^{*} / \mathrm{F}_{\mathrm{DAA}}=13.5^{* *} / \mathrm{F}_{\mathrm{Herb} \times \mathrm{DAA}}=4.3^{* *}\right)$; B - Glufosinateammonium $\left(\mathrm{F}_{\text {herb }}=4.9^{*} / \mathrm{F}_{\mathrm{DAA}}=15.4^{* *} / \mathrm{F}_{\mathrm{Herb} \times \mathrm{DAA}}=4.9^{* *}\right) ; \mathrm{C}-$ Paraquat $\left.\mathrm{F}_{\text {herb }}=6.7^{*} / \mathrm{F}_{\mathrm{DAA}}=15.2^{* *} / \mathrm{F}_{\text {Herb } \times \mathrm{DAA}}=3.1^{*}\right)$. DAA $=$ days after herbicide application 
It is likely that other chemoorganotrophic microorganisms, such as denitrificants, are favored by the use of glyphosate and glufosinate, as the highest exudation results in increased $\mathrm{C}$ and $\mathrm{N}$ availability in both the soil and these herbicidal molecules (unlike paraquat) do not affect the soil's chemoorganotrophic microbiota.

\section{Nitrification/denitrification}

In addition to reducing the agronomic effectiveness of $\mathrm{N}$ fertilization, $\mathrm{N}$ losses because of the denitrification-nitrification processes in soil may have a negative impact on the environment because considerable amounts of $\mathrm{N}_{2} \mathrm{O}$ are generated in these processes. This gas is considered the fourth-greatest contributor to the greenhouse effect, although it is present in the atmosphere and in the stratosphere in small amounts. Moreover, $\mathrm{N}_{2} \mathrm{O}$ is an intermediary in the ozone layer destruction process (Tabatabai et al., 1981; Griffith, 2005). It is estimated that approximately $20 \%$ of the global gas emissions of nitrogen oxides and elemental $\mathrm{N}$ are connected to agricultural activity. However, in countries such as Australia, agriculture may be responsible for $80 \%$ of these emissions (Australian Greenhouse Office, 2001).

The main processes that result in the gas loss of $\mathrm{N}$ oxides and elemental $\mathrm{N}$ are nitrification and denitrification. During nitrification (in the oxidation of $\mathrm{NH}_{4}$ into $\mathrm{NO}_{2}$ ), there may be slight production of nitrous oxide by a chemical dismutation of nitroxyl $(\mathrm{NOH})$ or by the action of nitrite reductase (Schimdt, 1982; Bremner, 1997). In this case, the formation of $\mathrm{N}_{2} \mathrm{O}$ may occur under aerobic conditions, during the nitrification. Although the $\mathrm{N}_{2} \mathrm{O}$ production by nitrification might, in some situations, have an emission potential similar to that of the denitrification process (Granli \& Bockman, 1994; Wang et al., 1997), denitrification seems to be the main $\mathrm{N}_{2} \mathrm{O}$ source in the soil (Tiedje, 1994).

Biological denitrification is defined as an anaerobic breathing process mediated by microorganisms that are able to use $\mathrm{NO}_{3}$ or $\mathrm{NO}_{2}$ as final electron acceptors. The main products of denitrification are $\mathrm{N}_{2}$ and $\mathrm{N}_{2} \mathrm{O}$, and the proportion of production of each gas varies according to the environmental conditions. There are more than 125 bacterial species that are capable of performing denitrification, including phototrophs, lithotrophs and organotrophs (the most important group).

The main environmental factors that interfere in denitrification rates are $\mathrm{O}_{2}$ supply, water content, temperature, organic matter, the presence of organic substances and ammonium $\left(\mathrm{NH}_{4}{ }^{+}\right)$and nitrate $\left(\mathrm{NO}_{3}^{-}\right)$concentration (Firestone \& Davidson, 1989). A number of studies have demonstrated that an increase in carbon content results in higher $\mathrm{N}_{2}$ and $\mathrm{N}_{2} \mathrm{O}$ emissions. Furthermore, $\mathrm{pH}$ may interfere in $\mathrm{N}_{2} \mathrm{O}$ and $\mathrm{N}_{2}$ emissions, as it affects nitrification, when it is reduced below 3.5 (Focht \& Verstraete, 1977).

\subsection{The effect of herbicides in nitrification/denitrification}

As discussed in section 4.1, chemoorganotrophic microorganisms may be favored by the application of some herbicides, and such is the case for glyphosate and glufosinate ammonium. Laboratory studies have demonstrated the increase of $\mathrm{N}_{2} \mathrm{O}$ emission in soils treated with glyphosate (Bollag \& Henninger, 1976; Yeomans \& Bremner, 1985; Carlisle \& Trevors, 1986), which might be attributable to the herbicide serving as a nutrient source to organisms and offering a competitive advantage to denitrificants through the killing of chemolithotrophic microorganisms. However, higher $\mathrm{N}_{2} \mathrm{O}$ emissions were also observed for soils with plants desiccated by these molecules (Robertson et al., 1987; Tenuta \& Beauchamp, 1996). This observation may be attributed to the indirect effects of the herbicide 
in the rizosphere due to the killing of the plants, such as the increase in promptly available carbon content and a reduction in the environment's $\mathrm{NO}_{3}$ absorption, leaving it more susceptible to microbial attack.

Most nitrifying microorganisms are chemolithotrophic and, therefore, they can show the metabolic routes present in the plants, including those that were affected by glyphosate or glufosinate ammonium. Damin et al. (2009) evaluated the $\mathrm{NO}_{3}{ }^{-}$content of two soils (haplustox and quartpsament) 90 days after the permanence of millet stubble desiccated with these herbicides. The $\mathrm{N}^{-\mathrm{NO}_{3}}{ }^{-}$content in the glyphosate and glufosinate treatments was reduced in the quartpsament, but not in the haplustox. The haplustox soil had a higher sorting capacity than the quatzpsament, as it could be noticed in the contents of the clay, the CTC and the organic matter of soils (Table 4). In fact, the $\mathrm{NH}_{4}{ }^{+}$availability to nitrifying microorganisms was lower in the haplustox than in the quatzpsament due to the higher ion absorption to the colloidal fraction of the soil. Moreover, the glyphosate showed a great affinity toward the iron and aluminum oxides and the hydroxides (Prata et al., 2000) common in the oxisoils. The strong connection between the herbicide and these fractions reduced the bioavailability of the product to the microorganisms.

Some authors have observed a rise in $\mathrm{NO}_{3}$ - content in the soil after the plants are killed. This result can be attributed to a higher availability of $\mathrm{NH}_{4}+$ in the soil as it stops being absorbed by the plant. Although the decrease in nitrification indicates a damaging effect to the microbiota, it is important to highlight that the conversion of $\mathrm{NH}_{4}{ }^{+}$into $\mathrm{NO}_{3}$ - in the soil may promote a higher risk of superficial water contamination by nitrate and a lower availability of the nutrient to future crops.

\begin{tabular}{|c|c|c|c|c|}
\hline \multirow[b]{2}{*}{ Treatments } & \multicolumn{2}{|c|}{$\mathrm{NH}_{4}{ }^{+}$} & \multicolumn{2}{|c|}{$\mathrm{NO}_{3}^{-}$} \\
\hline & Quartpsament & Haplustox & Quartpsament & Haplustox \\
\hline & \multicolumn{4}{|c|}{ mg per pot } \\
\hline Witness+ & 229.7 & 297.7 & 117.2baA & $31.5 \mathrm{aB}$ \\
\hline Glyphosate & 197.7 & 331.6 & $59.3 \mathrm{bA}$ & $34.2 \mathrm{aA}$ \\
\hline Glufosinate & 212.6 & 314.5 & $82.6 \mathrm{bA}$ & $21.4 \mathrm{aB}$ \\
\hline Average & $213.3 \mathrm{~b}$ & $314.6 \mathrm{a}$ & 86.4 & 29.1 \\
\hline Herbicide F & \multicolumn{2}{|c|}{$0.0 \mathrm{~ns}$} & \multicolumn{2}{|l|}{$3.8^{*}$} \\
\hline Soil F & \multicolumn{2}{|c|}{$24.3^{* *}$} & \multicolumn{2}{|c|}{$43.7^{* *}$} \\
\hline Interaction $\mathrm{F}$ & \multicolumn{2}{|c|}{$0.9 \mathrm{~ns}$} & \multicolumn{2}{|l|}{$4.1^{*}$} \\
\hline
\end{tabular}

+Witness (stubble with no application of herbicides); Means followed by the same letter in a given column indicates nonsignificant differences at the $5 \%$ level by Tukey's test. **, * $=$ Significant at $1 \%$ and $5 \%$ levels, respectively

Table $4 . \mathrm{NH}_{4}{ }^{+}$and $\mathrm{NO}_{3}$ - content in two soils 90 days after the permanence on the soil of Pennicetum glaucum stubble desiccated with herbicides (taken from Damin et al., 2009)

\section{Biological $\mathbf{N}$ fixation}

Biological $\mathrm{N}_{2}$ fixation (BNF) is an important entrance path for $\mathrm{N}$ in agroecosystems, and it is the main source of the nutrient in leguminous farming. In these plants, BNF is performed through the symbiosis between $\mathrm{N}$ fixing bacteria (NFB), which break the $\mathrm{N}_{2}$ triple bond through the action of the nitrogenase enzyme, reducing it to $\mathrm{NH}_{3}$, while the plants supply photosynthates to the bacteria. 
Only a small percentage of prokaryotes are able to accomplish BNF. Among these prokaryotes, however, there is high morphological, physiological and philogenetic diversity. In addition, $\mathrm{N}$ fixing micro-organisms are found among the heterotrophs, the anoxygenic phototrophs, the archaebacteria and the cyanobacteria. The main kinds of fixing bacteria, which are economically important, are Rhizobium and Bradyrhizobium, which are predominantly chemoorganotrophic metabolic proteobacteria, although there are some chemolitotrophic strains of Bradyrhizobium japonicum.

\subsection{Effect of herbicides}

Due to the diverse kinds of metabolism of $\mathrm{N}$ fixing bacteria, it is difficult to establish which conditions are favorable or unfavorable to NFB, as the effects of a determined factor will depend on the bacteria community present in the soil. This difficulty may be one of the reasons for the contradictory results in the literature concerning the effect of herbicides on nodulation.

The growth, survival and nitrogenase activity results vary according to the herbicide doses applied, the species/strains studied and the experimental conditions (Faizah et al., 1980; Mallik \& Tesfai, 1983; Eberbach \& Douglas, 1989; Martensson, 1992; Moorman et al., 1992; Mallik \& Tesfai, 1985; Moorman, 1986). Recently, Santos et al. (2004) observed differentiated responses in the growth of strains of native Brazilian Bradyrhizobium spp. because of the application of different commercial formulations of glyphosate. This differentiation reveals the importance of considering the adjuvant components of those herbicides in impact evaluations. With soybeans that are tolerant to glyphosate (Roundup Ready, RR), King et al. (2001) reported that the herbicide increased the number and decreased the weight of nodes. Jaworski (1972) observed a reduction of BNF after the application of glyphosate.

Some authors have attributed the BNF reduction after glyphosate application to the inhibition of the EPSPs enzymes in microorganisms (Malkores, 2000). Moorman (1986) evaluated the effect of glyphosate on the development of Bradyrhizobium spp. in the environment with and without the addition of amino acids. It was observed that the herbicide reduced the Bradyrhizobium spp. population only when no amino acids were added. It is worth stressing, however, that only chemolithotrophic microorganisms, such as some strains of Bradyrhizobium spp., should show this metabolic route.

Some authors have attributed the BNF reduction after glyphosate application to the physiological changes caused to the plants. It is common for nutritional disorders to happen in transgenic soybeans after glyphosate application, and two of them are particularly important: manganese ( $\mathrm{Mn})$ and iron $(\mathrm{Fe})$. The lack of manganese in the tissue may increase the ureide concentration in the aerial parts, signaling to the BNF to stop fixation (Gordon, 2007). Moreover, the application of the herbicide reduces the production of flavonoids, substances that stimulate the genetic expression of nodulation.

\section{Final consideration}

The effect of herbicides on a soil-plant system's $\mathrm{N}$ loss and on the mineralization rates of vegetable residues should be considered when predicting the $\mathrm{N}$ availability to plants, in nutrient-caused environmental impact studies, in production cost estimations and in decision making concerning the appropriate time to apply $\mathrm{N}$ doses in areas under a tillage system. This kind of information is important for creating managing strategies that increase 
the efficiency of $\mathrm{N}$ fertilization and reduce the environmental impacts caused by the use of fertilizers and herbicides.

\section{References}

Accinelli, C., Screpanti, C., Dinelli \& G.; Vicari, A. (2002) Short-time effects of pure and formulated herbicides on soil microbial activity and biomass. International Journal of Environmental and Analytical Chemistry, v.82, p. 519-527.

Argenta, G., Silva, P.R.F., Fleck, N. G., Bortoline, C. G., Neves, R. \& Agostinetto, D. (2001) Efeitos do manejo mecânico e químico da aveia-preta no milho em sucessão e no controle do capim-papuã. Pesquisa Agropecuária Brasileira, v. 36, p. 851-860.

Asman, W.Ah., Sutton, M.A. \& Schjorring, J.K. (1998) Ammonia: emission, atmospheric transport and deposition. New Phytologist, v.139, p.27-48.

Australian Greenhouse Office, (2001). National Greenhouse Gas Inventory. 1999. With Methodology Supplements. Australian Greenhouse Office, Commonwealth of Australia, Canberra.

Bremner, J.M. Sources of nitrous oxide in soils. (1997) Nutrient Cycling in Agroecosystems, v.49, p.7-16.

Britto D.T. \& Kronzucker, H.J. (2001). $\mathrm{NH}_{4}{ }^{+}$toxicity in higher plants: a critical review. Journal of Plant Physiology, v.159, p.567-584.

Bollag, J. M. \& Henninger, N. M. (1976). Influence of pesticides on denitrification in soil and with an isolated bacterium. Journal of Environmental Quality, v.5, p. 15-19.

Cakmak, I. 2007. Efeitos do glyphosate na nutrição de micronutrientes de plantas. Informações Agronômicas, Piracicaba, n.119, p.5-8, set.

Carlisle, S. M. \& Trevors, J. T. (1986). Effect of the herbicide glyphosate on nitrification, denitrification and acetylene reduction in soil. Water Air Soil Pollut. v.29, p.391-401.

Dakora, F.D. \& Phillips, D.A. (2002) Roots exudates as mediators of mineral acquisition in low-nutrient environments. Plant and Soil, v.245, p.35-47.

Damin, V., Franco, H.C.J, Moraes, M.F, Franco, A., Trivelin, P.C.O. (2008) Nitrogen loss in Brachiaria decumbens after application of glyphosate or glufosinate-amonnium. Scientia Agricola, Piracicaba, v.65, n.4, p.402-407.

Damin, V., Trivelin, P. C. O. \& Barbosa, T. G. (2009). Mineralização do nitrogênio da stubble de milheto dessecado com herbicides. Revista Brasileira de Ciência do Solo, v. 33, p. 925-934.

Damin, V.; Trivelin, P.C.O.; Franco, H.C.J.F. \& Barbosa, T.G. (2010a)Nitrogen (15N) loss in soil-plant system after herbicides application in Penissetum glaucum. Plant and Soil, v. 328, p. 245-252.

Damin, V., Trivelin, P. C. O., Carvalho, S. J. P., Moraes, M. F. \& Barbosa, T. G. (2010b) Herbicides application increases nitrogen $(15 \mathrm{~N})$ exudation and root detachment of Brachiaria decumbens Stapf. Plant and Soil . DOI: 10.1007/s11104-010-0402-6, on-line first.

Damin, V., Trivelin, P. C. O., Barbosa, T. G., Carvalho, S. J. P \& Moraes, M.F. (2010, no prelo). mineralization and corn recovery of 15 Nitrogen from black oats residues treated with herbicides. Journal of Plant Nutrition. 
Descalzo, R.D., Punja, Z.K., Levesque, C.A. \& Rahe J.E. (1996). Identification and role of Pythium species as glyphosate synergists on bean (Phaseolus vulgaris L. Topcrop) grown in different soils. Mycological Research, v.100, p.971-978.

Deubel, A., Gransee, A. \& Merbach, W. (2000) Transformation of organic rhizodephositions by rhizosfere bacteria and its influence on the availability of tertiary calcium phosphate. Journal of Plant Nutrition and Soil Science, v.163, p.387-392.

Duke, S.O. \& Hoagland, R.E. (1995) Effects of glyphosate on metabolism of phenolic compounds. In: Grossbard, E.; Atkinson, D. (Ed.). The herbicide glyphosate. London: Butterworths. p. 75-91.

Eberbach, P.L.; Douglas, L.A. Herbicide effects on the growth and nodulation potential of Rhizobium trifolii with Trifolium subterraneum L. Plant and Soil, v.119, p.15-23, 1989.

Faizah, A.W.; Broughton, W.J.; John, C.K. Rhizobia in tropical legumes. XI. Survival in the seed environment. Soil Biology and Biochemistry, v.12, p.219-227, 1980.

Farquhar, G.D.; Firth, P. M.; Wetselaar, R.; Weir, B. On the gaseous exchange of ammonia between leaves and the environmental: determination of the ammonia compensation point. Plant Physiology, Rockville, v.66, n.4, p. 710-714, 1980.

Focht, D.D., Verstraete. W. Biochemical ecology of nitrification and denitrification. In 'Advances in microbial ecology'. (Ed. M. Alexander) pp. 135-214. (Plenum Press: New York), 1977.

Francis, D. D.; Schepers, J. S.; Vigil, M.F. Post-anthesis nitrogen loss from corn. Agronomy Journal, Madison, n.85, n.3, p. 659-663, 1993.

Ghosh, S.; Paliyath, P.; Peirson, D.; Fletcher, R.A. Nitrogen mobilization during senescence. In: SRIVASTAVA, H.S.; SINGH, R.P. (Ed.). Nitrogen nutrition in higher plants. New Delhi: Associated Publishing, 1995. p. 337-365.

Gordon, B. Adubação com manganês em soja convencional e soja resistente ao glifosato. Informações Agronômicas, Piracicaba, n.117, p.6-7, 2007.

Grossbard, E. Effects of glyphosate on the microflora: with reference to the decomposition of treated vegetation and interaction with some plant pathogens. In: Grossbard, E.; Atkinson, D. (Ed.). The herbicide glyphosate. Londres: Butterworths, 1985. p.159185.

Granli, T.; Bockman, O.C. Nitrous oxide from agriculture. Journal of Agricultural. Science. v.12, p.7-128, 1994.

Griffith, 2005 GRIFFITH, J. Nitrogen pollution turn bays and rivers into dead zones. Ithaca: College of Agriculture and Life Sciences News, Cornel University, 2005. p.19-21.

Groffman, P.M. Nitrogen in the environment. In: SUMMER, M.E. (Ed.) Handbook of soil science. Boca Raton: CRC Press, 2000. p.190-200.

Haney R.L.; Senseman, S.A.; Hons, R.M.; Zuberer, D.A. Effect of glyphosate on soil microbial activity and biomass. Weed Science, Lawrence, v.48, n.1, p.89-93, 2000.

Haney, R. L.; Senseman, S. A.; Hons, F. M. Effect of Roundup Ultra on microbial activity and biomass from selected soils. Journal of Environmental Quality, Madison, v. 31, n. 3, p.730-735, 2002.

Heinzmann, F.X. Resíduos culturais de inverno e assimilação de nitrogênio por culturas de verão. Pesquisa Agropecuária Brasileira, Brasília, v.20, n.9, p.1021-1030, 1985. 
Holtan-Hartwig, L.; Bockman, O.C. Ammonia exchange between crops and air. Norwegian Journal of Agricultural Sciences, Norwegian, v.14, Supplement, p.1-41, 1994.

Hoagland, R.E.; Duke, S.O.; Elmore, C.D. Effects of glyphosate on metabolism of phenolic compounds. III. Phenylalanine ammonia-lyase activity, free amino acids, soluble protein and hydroxiphenolic compounds in axes of dark-grown soybeans. Physiologia Plantarum, Kobenhavn, v. 46, n.4, p. 357-366, 1979.

Holland, J.N.; Cheng, W.; Crossley, D.A. J. Herbivore induced changes in plant carbon allocation assestment of below-ground C fluxes using carbon-14. Oecologia, Berlim, v.107, n.1, p.87-94, 1996.

Jaworski, E.G. Mode of action of N-phosphonomethylglycine: inhibition of aromatic amino acid biosynthesis. Journal of Agricultural and Food Chemistry, Easton, v. 20, n. 6, p. 1195-1198, 1972.

Johal, G.S.; Rahe J.E. Effect of soilborne plant-pathogenic fungi on the herbicidel action of glyphosate on bean seedlings. Phytopathology, Lancaster, v.74, n.7, p. 950-955, 1984.

King, C.A.; Purcell, L.C.; Vories, E.D. Plant growth and nitrogenase activity of glyphosatetolerant soybean in response to foliar glyphosate applications. Agronomy Journal, v.93, p.179-186, 2001.

Klein, D.A.; Frederick, B.A.; Biondini, M.J.T. Rhizosphere microorganisms effects on soluble amino acids, sugars and organic acids in the roor zone of Agropyron cristatum, A. smithii and Bouteloua gracilis. Plant and Soil, Dordrecht, v.110, n.1, p.19-25, 1988.

Kraffczyk, I.; Trolldenier, G.; Beringer, H. Soluble root exudates of maize (Zea mays L.): influence of potassium supply and rhizosfere microorganisms. Soil Biology and Biochemistry, Amsterdam, v.16, n.4, p.315-322, 1984.

Kremer, R.J.; Means, N.E.; Kim, S. Glyphosate affects soybean root exudation and rhizosphere microorganisms. International Journal of Environmental Analytical Chemistry, Oxfordshire, v. 85, n.15, p. 1165-1174, 2005.

Laurière, C.; Daussand, J. Identification of the ammonium dependent isoenzymes of glutamine dehidrogenase as the form induced by senescence or darkness stress in the first leaf of wheat. Physiologia Plantarum, Kobenhavn, v.58, n.1, p. 89-92, 1983.

Levesque, C.A.; Rahe, J.E. Herbicide interactions with fungal root pathogens, with special reference to glyphosate. Annual Review of Phytopathology, Palo Alto, v.30, n.1, p.579-602, 1992.

Levesque, C.A.; Rahe, J.E.; Eaves, D.M. Fungal colonization of glyphosate-treated seedlings using a new root plating technique. Mycological Research, Cambridge, v.97, n.3, p.299-306, 1993.

Levesque, C.A.; Rahe, J.E.; Eaves, D.M. The effect of soil heat treatment and microflora on the efficacy of glyphosate in seedlings. Weed Research, Oxford, v. 32, n.5, p.363373, 1992.

Liu, L.; Punja, Z. K.; Rahe, J. E. Altered root exudation and suppression of induced lignification as mechanisms of predisposition by glyphosate of bean roots (Phaseolus vulgaris L.) to colonization by Pythium spp. Physiological and Molecular Plant Pathology, London, v.51, n.2, p. 111-127, 1997. 
Malkones, H.P. Comparason of the effects of differently formulated herbicides on soil microbial activities - a review. Journal of Plant Diseases and Protection, Sttutgart, v.8, p.781-789, 2000.

Mallik, M.A.B.; Tesfai, K. Compatibility of Rhizobium japonicum with commercial pesticides in vitro. Bulletin of Environmental Contamination and Toxicology, v.31, p.432-437, 1983.

Mallik, M.A.B.; Tesfai, K. Pesticidal effect on soybean-rhizobia symbiosis. Plant and Soil, v.85, p.33-41, 1985.

Manderscheid, R.; Schaaf, S.; Mattsson, M.; Schjoerring, J.K. Glufosinate treatment of weeds results in ammonia emission by plants. Agriculture, Ecosystems and Environment, Amsterdam, v.109, n.1/2, p. 129-140, 2005.

Marschner, H. Mineral nutrition of higher plants. $2^{\text {nd }}$.ed. London, UK: Academic Press, 1995. 889p.

Merbach, W.; Schlze, J.; Richert, M.; Rrocco, E.; Mengel, K. A comparison of different ${ }^{15 N}$ application techniques to study the net rhizodeposition in the plant-soil system. Journal of Plant Nutrition and Soil Science, Weinhein, v.163, n.3, p.375-379, 2003.

Moorman, T.B. Effects of herbicides on the survival of Rhizobium japonicum strains. Weed Science, v.34, p.628-633, 1986.

Moorman, T.B.; Becerril, J.M.; Lydon, J.; Duke, S.O. Production of hydroxybenzoic acids by Bradyrhizobium japonicum strains after treatment with glyphosate. Journal of Agricultural and Food Chemistry, v.40, p.289-293, 1992.

Moreira, F.M.S.; Siqueira, J.O. Microbiologia e bioquímica do solo. Lavras: UFLA, 2006. $729 \mathrm{p}$.

Nakasathien, S.; Israel, D. W.; Wilson, R. F.; Kwanyuen, P. Regulation of seed protein concentration in soybean by supra-optimal nitrogen supply. Crop Science, Madison, v.40, n.5, p. 1277-1284, 2000.

Nguyen, C. Rhizodeposition of organic C by plant, mechanisms and controls. Agronomie, Paris, v.23, n.5/6, p.375-396, 2003.

Oliveira, F.H.T.; Novais, R.F.; Alvarez V.V.H.; Cantarutti, R.B.; Barros, N.F. Fertilidade do solo no sistema plantio direto. In: Alvarez, V.V.H.; Schaefer, C.E.G.R.; Barros, N.F.; Mello, J.W.V.; Costa, L.M. (Ed.) Tópicos em ciência do solo. v.2. Viçosa : Sociedade Brasileira de Ciência do Solo, 2002. p.393-486.

Paterson, E. Importance of rhizodeposition in the coupling of plant and microbial productivity. European Journal of Soil Science, Oxford, v.54, n.4, p.741-750, 2003.

Parton, W.J.; Morgan, J.A.; Altenhofen, J.M.; Harper, L.A. Ammonia volatilization from spring wheat plants. Agronomy Journal, Madison, v.80, n.3, p.419-425, 1988.

Prata, F.; Lavorenti, A.; Regitano, J.B.; Tornisielo, V.L. Influência da matéria orgânica na sorção e dessorção do glifosato em solos com diferentes atributos mineralógicos. Revista Brasileira de Ciência do Solo, Viçosa, v.24, n.4, p.947-951, 2000.

Ratcliffe, A.W.; Busse, M.D.; Shestak, C.J. Changes in microbial community structure following herbicide (glyphosate) additions to forest soils. Applied Soil Ecology, Amsterdam, v.34, n.2/3, p.114-124, 2006. 
Ragster, L.E.; Chrispeels, M.J. Autodigestion in crude extracts of soybean leaves and isolated chloroplasts as a measure of proteolytic activity. Plant Physiology, Rockville, v.67, n.1, p.104-109, 1981.

Robertson, G. P., Vitousek, P. M., Matson, P. A. and Tiedje, J. M. 1987. Denitrification in a clear-cut Loblolly pine (Pinus taeda L.) plantation in the southeastern U.S. Plant Soil 99: 119-129.

Santos, J.B.; Jacques, R.J.S.; Procópio, S.O.; Kasuya, M.C.M.; Silva, A.A.; Santos, E.A. Efeitos de diferentes formulações comerciais de glyphosate sobre estirpes de Bradyrhizobium. Planta Daninha, v.22, p.293-299, 2004.

Sherlock, R.R.; Freney, J.R.; Smith, N.P.; Cameron, K.C. Evaluation of a sampler for assessing ammonia losses from fertilized fields. Fertilizer Research, Springer, v.21, n.2, p. 61-67, 1989.

Schimidt, E. Nitrification in soil. In: STEVENSON, F.J.; BREMNER, J.M.; HAUCK, R.D.; KEENEY, D.R. (Ed.) Nitrogen in agricultural soils. Madison: American Society of Agronomy, 1982. 940p. (Agronomy Series, 22)

Schjoerring, J.K.; Kyllingsbaek, A.; Mortnsen, J.V.; Byskovi-Nielsen, S. Field investigations of ammonia exchange between barley plants and the atmosphere. I. Concentration profiles and flux densities of ammonia. Plant Cell Environment, Heidelberg, v.16, n.2, p. 161-167, 1993.

Schjoerring, J. K.; Husted, S.; Mattsson, M. Physiological parameters controlling plantatmospheric ammonia exchange. Atmosferic Environmental, Amsterdam, v.32, n.3, p.491-498, 1998.

Snapp, S.S.; Borden, H. Enhanced nitrogen mineralization in mowed or glyphosate treated cover crops compared to direct incorporation Plant and Soil, Dordrecht, v.270, n.1/2, p.101-112, 2005.

Sutton, M.A.; Pitcairn, C.E.R.; Fowler, D. The exchange of ammonia between the atmosphere and plant communities. In: Begon, M.; Fitter, A.H. Advances in Ecological Research, New York, v.24. p.301-393, 1993.

Tabatabai, M.A.; Burwell, R.E.; Keeney, D.R.; Logan, T.J.; Nelson, E.W.; Olson, R.A.; Randall, G.W.; Timmons D.R.; Verry, E.S.; White, E.M. Nutrient concentrations and accumulations in precipitation over the North Central Region. Ames: Iowa State University, 1981. 142p. (Research Bulletin, 594)

Tenuta, M. and Beauchamp, E. G. Denitrification following herbicide application to a grass sward. Canadian Journal of Soil Science 76:15-22, 1996

Tiedje, J.M. Denitrifiers. In: Weaver, W.; Angel, J.S.; Bottomley, P.S. (Ed.) Methods of soil analysis. Part 2. Microbiological and biochemical properties. Madison: Soil Science Society of America, 1994. p. 245-267.

Trivelin, P. C. O. Utilização do nitrogênio pela cana-de-açúcar: três casos estudados com uso do traçador ${ }^{15}$ N. 2000. 143p. Tese (Livre Docência) - Escola Superior de Agricultura "Luiz de Queiroz", Universidade de São Paulo, Piracicaba, 2000.

Tuffi Santos, L.D.; Santos, J.B.; Ferreira, F.A.; Oliveira, J.A.; Bentivenha, S.; Machado, A.F.L. Exsudação radicular de glyphosate por Brachiaria decumbens e seus efeitos em plantas de eucalipto. Planta Daninha, Viçosa, v.26, n.2, p.369-374, 2008. 
Zabaloy, M. C.; Gómez, M. A. Microbial respiration in soils of the Argentine pampas after metsulfuron-methyl, 2,4-D, and glyphosate treatments. Communications in Soil Science and Plant Analysis, Philadelphia, v.39, n.3/4, p.370-385, 2008.

Wang, M.Y.; Siddiqi, M.Y.; Ruth, T.J.; Glass, A.D.M. Ammonium uptake by rice roots. I. Fluxes and subcellular distribution of ${ }^{15} \mathrm{NH}_{4}{ }^{+}$. Plant Physiology, Rockville, v.103, n.4, p.1249-1258, 1993

Wetselaar, R.; Farquhar, G. D. Nitrogen losses from tops of plants. Advances in Agronomy, New York, v.33, n.1, p. 263-302, 1980.

Yeomans J.C.; Bremner, J.M. Denitrification in soil: Effects of herbicides. Soil Biology and Biochemistry, v.17, p.447-452, 1985. 


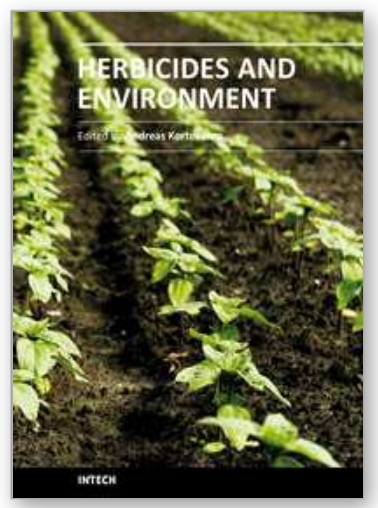

\author{
Herbicides and Environment \\ Edited by Dr Andreas Kortekamp
}

ISBN 978-953-307-476-4

Hard cover, 746 pages

Publisher InTech

Published online 08, January, 2011

Published in print edition January, 2011

Herbicides are much more than just weed killers. They may exhibit beneficial or adverse effects on other organisms. Given their toxicological, environmental but also agricultural relevance, herbicides are an interesting field of activity not only for scientists working in the field of agriculture. It seems that the investigation of herbicide-induced effects on weeds, crop plants, ecosystems, microorganisms, and higher organism requires a multidisciplinary approach. Some important aspects regarding the multisided impacts of herbicides on the living world are highlighted in this book. I am sure that the readers will find a lot of helpful information, even if they are only slightly interested in the topic.

\title{
How to reference
}

In order to correctly reference this scholarly work, feel free to copy and paste the following:

Virginia Damin and Paulo Trivelin (2011). Herbicides Effect on Nitrogen Cycling in Agroecossystems, Herbicides and Environment, Dr Andreas Kortekamp (Ed.), ISBN: 978-953-307-476-4, InTech, Available from: http://www.intechopen.com/books/herbicides-and-environment/herbicides-effect-on-nitrogen-cycling-inagroecossystems

\section{INTECH}

open science | open minds

\section{InTech Europe}

University Campus STeP Ri Slavka Krautzeka 83/A 51000 Rijeka, Croatia Phone: +385 (51) 770447 Fax: +385 (51) 686166 www.intechopen.com

\section{InTech China}

Unit 405, Office Block, Hotel Equatorial Shanghai No.65, Yan An Road (West), Shanghai, 200040, China 中国上海市延安西路65号上海国际贵都大饭店办公楼 405 单元 Phone: +86-21-62489820

Fax: $+86-21-62489821$ 
(C) 2011 The Author(s). Licensee IntechOpen. This chapter is distributed under the terms of the Creative Commons Attribution-NonCommercialShareAlike-3.0 License, which permits use, distribution and reproduction for non-commercial purposes, provided the original is properly cited and derivative works building on this content are distributed under the same license. 